\title{
Linear and Non-linear Approaches in Testing Managerial Ownership on the Firm Value: Evidence Indonesian Firms
}

\author{
Yulianto, Arief $\left({ }^{1}\right.$; Kiswanto $\left(^{2}\right.$; Widiyanto $\left(^{3}\right.$; Yulianto, Agung $\left(^{4}\right.$ \\ ${ }^{d, 2,3,4}$ : Faculty of Economics, State University of Semarang
}

\begin{abstract}
The purpose of this study was to determine the effect of managerial ownership on firm value through the linear and non-linear approaches. This study was conducted on 54 observations which included the Indonesian Most Trusted Companies in 2008 until 2011. The results of this study showed that managerial ownership does not have a linear effect on the firm value, but have non-linear effect on the firm value. Turning point in the managerial ownership were $3.36 \%$ and $15.15 \%$. At ownership of $0 \%-3.36 \%$, it may cause a decrease in the value of the company (entrenchment effect) while $3.36 \%$ to $15.15 \%$ ownership may result in an increase in the value of the company (alignment effect)
\end{abstract}

Keywords: Managerial Ownership, Linier, Non-Linier Approaches, Firm Value

\section{Introduction}

Jensen and Meckling (1976) assert that if an increase in insider stock ownership, then there would be a decline in the use of company resources for the benefit of the insider. So this might cause to the unification of insider's shareholder interests with other shareholders'. In this condition, the conflicts among outsider and insider shareholders would not happen (convergence hypothesis).

Agency relationship is the relationship between managers (as the agents) and owners (like shareholders or principals). At the moment the company is still owned $100 \%$ by the owner, will not lead to problems in the agency relationship(agency problems). However, when the managerial ownership is less than $100 \%$ then it might potentially lead to agency problems. This is because the managerial agent of the principals often acts in certain interests and ignoring the interests of other shareholders.

Perspective of agency theory explains that when the managers have little stock of the company and the rest is spread out so it cannot affect the decision making of the company, then the manager will use the company's assets for the benefit of managers compared to the interests of other shareholders (Berle and Means, 1932). Furthermore, Jensen and Meckling (1976) describe that the relationship further in cost and managerial stockownership. Cost of deviation (overall cost) of the value of the company willg o down, if there is an increase in managerial ownership. At the proportional of managerial hare ownership increases, it will lead to overall cost increases, then the manager is less likely to squander corporate resources.

But at a certain point (as the turning point) when the managerial ownership increases, it will lower the value of the company because of the magnitude of managerial power to take decisions for the benefit of managerial enterprise (Ruan et al., 2011; Herry and Hamin, 2005). Therefore, in order to achieve good corporate governance, the government issued Government Regulation (Peraturan Pemerintah-PP) No. 81 of 2007 and the Finance Minister Regulation (PMK) No.238/PMK.03/2008. The implementation of Corporate Governance in the Voluntary Indonesia (Ministry of Finance and Bapepam-LK, 2010) and unlike in the United States which is mandatory (Kamal, 2011), then there are no rules about the number of managerial stock ownership or insiders. In regulation government regulation (PP) No.81 of 2007 and the Finance Minister Regulation (Peraturan Menteri Keuangan-PMK) No.238/PMK.03/2008 which provide tax relief on the amount of $5 \%$ for companies that have a publics take of at least $40 \%$ of all paid shares. The objective of the regulations (PP and PMK) is to reduce the concentration of ownership of shares insiders but does not explain the number of managerial stock ownership or insiders.

On the various previous studies showed linear results on the effect of managerial ownership on firm value such as a study by Lee and Ryu (2003) which found that managerial ownership affects firm value and not based on the proportion of insider ownership. Din and Javid (2011); Hiraki et al. (2001) found positive results between insider stock ownership with firm values. While Fahlenbrach and Stulz (2008); Wahla et al (2011) found a negative effect of managerial ownership on firm value. However Rustendi and Jimmi (2008); Hamidullah and Shah (2011) found that stock managerial ownership does not affect the value of the company.

In contrast to the previously mentioned, there are also researches that say that there are significant non-linear (quadratic) as the effect of managerial ownership on the firm value in the U-shaped (Simoneti and Gregoric, 2004) or inverted-U shaped (Herry and Hamin, 2005; Benson and Davidson, 2009; Mueller and Spitz, 2002). This is an indication that the proportion or percentage of managerial stock ownership has effect on the firm value. In theU-shaped, then the small percentage of managerial stock ownership might lower the value of 
the company, but in the event of an increase in ownership will increase the value of the company. In contrast to the inverted U-shape, when the managerial ownership is low, it may increase the value of the company, but the increase in managerial ownership will decrease the value of the company.

In addition, the research found that explains the cubic shape of the influence of managerial stock ownership on firm value, which is the N-shaped of Morck et al. (1988); Iturralde et al. (2011); Torre et al. (2011); Ruan et al. (2011); Kim et al. (2011). Faccio and Lasfer (1999) emphasize that the N-shaped likely to occur in such companies that are growing. In this $\mathrm{N}$-shaped, the proportion of middle managerial stock ownership might result in the value of the company down, but for either high or low proportion of managerial ownership might result in an increase in the value of the company.

\section{Literature Review and Hypotheses}

Such agency problem might occur when the company's stock ownership is not $100 \%$ owned by the owners (principals). This condition at the proportional of principals delegating to the agent (manager) to manage the company(agency relationship) with the aim that managers act in the interests of the agent. But in its development managers often make decisions of the company which are not in favor of the interests of the principals(Jensen and Meckling, 1976).

Din and Javid (2011) who conducted a study of 60non-financial companies included in the 100 companies the index at the Karachi Stock Exchange (KSE) in the period 2000 to 2007. The results showed that the effect of managerial ownership on the firm value of a positive linear at the the majority of the company is owned by the family. This is because the manager at a relatively high share ownership will do the hard work and the right investment decisions that enhance shareholder value. This is consistent with Hiraki et al. (2001).

Wahla et al. (2012) conducted a study of 61non-financial companies included in the Karachi Stock Exchange (KSE) in the period 2008 to 2010 and found results that managerial ownership has a negative effect on the firm value when there is no concentration of ownership in the company(dispersed ownership). These conditions resulted in the ownership only concentrated on managers as shareholders so that it might perform the action by using company resources for his interests. This is consistent with Fahlenbrach and Stulz (2008). Based on previous research, it was found that managerial ownership influences both positive and negative linear to the value of the company, so that the hypothesis can be formulated

Hypothesis 1: Managerial stock ownership has linear effect to the firm value.

In contrast to the previous studies and Lee and Ryu (2003) who explain that managerial stock ownership is not based on the proportion of ownership, it affects the value of the company. Herry and Hamin (2005) found results that managerial stock ownership will affect the firm value, depending on the proportion of the ownership. At the managerial ownership is relatively small it will affect the increased value of the company(alignment effect), but at the proportional of high managerial ownership will decrease the value of the company (entrenchment effect). This is consistent with Benson and Davidson (2009) and Mueller and Spitz (2002) which also describes the non-linear of inverted U-shaped is the managerial stock ownership and corporate value. So the second hypothesis can be formulated as follows:

Hypothesis 2: Managerial stock ownership has non-linear U-inverted effect to the firm value.

On the other hand, Simoneti and Gregoric (2004) who conducted a study on 182 Slovenian companies in 1995 to 1999 explain the results of the research that managerial stock ownership has the effect of non-linear U-shaped. At low managerial ownership, it will lower the value of the company, otherwise in the event of an increase in managerial ownership will decrease the value of the company, with the turning point of managerial ownership by $25 \%$. Based on this research, the third hypothesis can be formulated as follows:

Hypothesis 3: Managerial stock ownership has non-linear $U$ effect to the firm value.

In addition to the non-linear effect shapes which have been mentioned, Morck et al, (1988) describes that the effect of managerial stock ownership in the non-linear shaped to the value of the company, which is Nshaped. This study used piecewise linear regression approach to estimate the relationship Tobins $\mathrm{Q}$ as a proxy of the value of the company and insider ownership on 371 companies listed in the Fortune 500 in 1980. The results showed that when the managerial ownership of 0 to $5 \%$ have a positive relationship with the Tobins Q (convergence hypothesis), at 5 to $25 \%$ was found a negative relationship (entrenchment hypothesis) after that there was a positive relationship in the ownership of more than $25 \%$ (convergence hypothesis). Various studies support this findings are such Iturralde et al. (2011); Torre et al. (2011); Ruan et al. (2011); Kim et al. (2011); Faccio and Lasfer(1999). The fourth hypothesis that can be formulated as follows:

Hypothesis 4: Managerial stock ownership has non-linear $\mathrm{N}$ effect to the firm value.

\section{Research Method}

The results showed that the companies which were following survey of The Indonesian Most Trusted Company which was conducted by IICG and SWA Magazine during the period of 2008 to 2011 as many as 79 observations. There were 26 observations that have no managerial stock ownership so that the companies which 
were utilized as sample of 54 observations. Based on industry category of JASICA(Jakarta Stock Industrial Classification) the distribution of the sample were 7 companies $(26.92 \%)$ which are included in the category of the primary sector, 4 companies $(15.28 \%)$ as secondary or manufacturing sector and 15 companies $(57.69 \%)$ as tertiary or services sector. The data in this study were secondary data, namely (a) for managerial stockownership which was obtained from the company of annual report of 2008 to 2011(MO) (b) share price(SP) as a proxy of the firm value which was derived from the IDX Statistics. Analysis tools were used in the linear regression model and non-linear. Linear regression model used to test the first hypothesis that can be formulated as follows:

$\mathrm{SP}=\mathrm{a}+\mathrm{b} 1 \mathrm{MO}$

While quadratic model which was used to test the relationship the non-linear U-shaped or U-inverted quadratic can be formulated as follows:

$\mathrm{SP}=\mathrm{a}+\mathrm{b} 1 \mathrm{MO}+\mathrm{b} 2 \mathrm{MO}^{2}$

Cubic model which was used to test the relationship between $\mathrm{N}$-shaped non-linear thus the model can be formulated as follows:

$$
\mathrm{SP}=\mathrm{a}+\mathrm{b} 1 \mathrm{MO}+\mathrm{b} 2 \mathrm{MO}^{2}+\mathrm{b} 3 \mathrm{MO}^{3}
$$

\section{Results and Discussions}

Most of the observations of as many as 52 or $96.30 \%$ showed where the managerial stock ownership was less than $1 \%$, and each 1 or $1.85 \%$ managerial ownershiphas $1-2 \%$ and more than $2 \%$. The average managerial stock ownership was $0.44 \%$, and the share price of IDR 5,136. For the variance in managerial ownership was at 2.44, and the price of shares of IDR 7,554. This is an indication that the stock prices of companies included in the Indonesian Most Trusted Companies have heterogeneous characteristics.

Based on testing result showed that the managerial stock ownership has no effect to the firm values, as presented in the following table:

\section{Table 1Linear Hypothesis Testing}

Coefficients

\begin{tabular}{|c|c|c|c|c|c|c|}
\hline \multirow{2}{*}{\multicolumn{2}{|c|}{ Model }} & \multicolumn{2}{|c|}{$\begin{array}{l}\text { Unstandardized } \\
\text { Coefficients }\end{array}$} & \multirow{2}{*}{$\begin{array}{c}\text { Standardi } \\
\text { zed } \\
\text { Coeff icien } \\
\text { ts }\end{array}$} & \multirow[b]{2}{*}{$t$} & \multirow[b]{2}{*}{ Sig. } \\
\hline & & B & Std. Error & & & \\
\hline & (Constant) & 7,686 & ,195 & & 39,483 &, 000 \\
\hline & MANJ & $-11,692$ & 7,939 &,- 200 & $-1,473$ & ,147 \\
\hline
\end{tabular}

a. Dependent Variable: LNHS

Managerial ownership has an average score of $0.44 \%$ of which has insignificant effect on the firm value. Other researches which have similar results were conducted by Rustendi and Jimmi (2008) in Indonesia and Hamidullah and Shah (2011) in Pakistan. Managerial ownership which increases is the power to make decisions on the company, but with a relatively small proportion of the average, then the manager cannot make decisions that affect the value of the company.

Non-linear testing with maximum managerial stock ownership of $17.88 \%$ showed the results as presented in the following table:

Table 2 Non-linear hypothesis testing

Coefficients ${ }^{\mathrm{a}}$

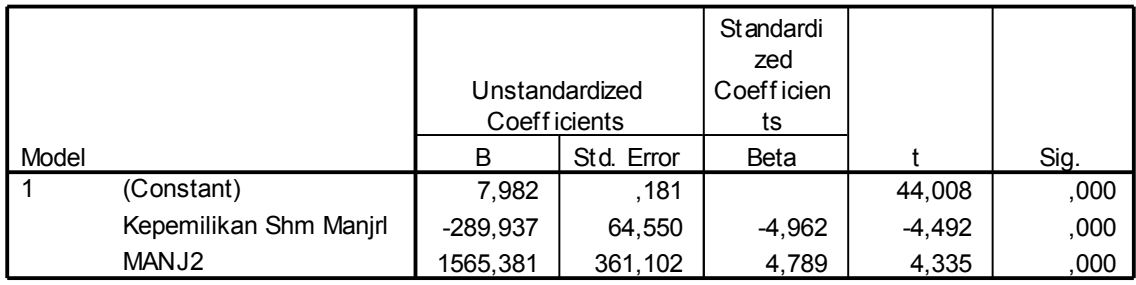

a. Dependent Variable: LNHS

The results of non-linear cubic testing cannot be conducted because the $\mathrm{MO}^{3}$ was excluded from the model, so that only the quadratic testing that can be conducted. Table 2 illustrates that the presence of managerial stock ownership quadratic (MO2) then it will have a significant effect on the firm value. At the proportional of managerial ownership is relatively low it will lower the value of the company, but with the increase in managerial ownership, it will increase the value of the company. This result is an indication of the 
effect of managerial ownership on firm value is U-shaped; such similar research was also conducted by Simoneti and Gregoric (2004). The turning point can be determined by the following formula:

Table 2 above describes that there is significant results in non-linear, which can be formulated as

follows:

$\mathrm{Y}=\mathrm{a}+\mathrm{bx}+\mathrm{cx}^{2}$

$\mathrm{Y}=7.98-289.94 \mathrm{X}+1565.38 \mathrm{X}^{2}$

Based on the above equation, it can be identified that the coefficients $a=1565.38 ; \quad b=-289.94$ and $\mathrm{c}=7.98$, so that when the coefficients are inserted into the parabolic equation(quadratic) will have turning points as follows:

$$
\begin{aligned}
& X_{1,2}=\frac{-b \pm \sqrt{b^{2}-4 a c}}{2 a} \\
& X_{1,2}=\frac{289.94 \pm \sqrt{-289.94^{2}-4.1565 .38 .7 .98}}{3130.762} \\
& X_{1,2}=\frac{289.94 \pm \sqrt{34083.9794}}{3130.762} \\
& X_{2}=\frac{289.94+184.6184}{3130.762}=\frac{474.6}{3130.762}=15,15 \% \\
& X_{1}=\frac{289.94-184.6184}{3130.762}=\frac{105.3}{3130.762}=3.364 \%
\end{aligned}
$$

These results provide additional evidence that occur on the U-shaped effect of managerial stock ownership on the firm value with significant turning points, $3.36 \%$ and $15.15 \%$. At the proportional of managerial stock ownership is less than $3.36 \%$, the decision was made to lower the value of the company, while at the proportional of ownership increases up to $15.15 \%$, it may increase the value of the company instead.

Simoneti and Gregoric (2004) explain that a relatively small managerial stock ownership is low representation of managerial motivation in the company and tend to consolidate the majority of shareholder, resulting in a decrease in the value of the company. But when the managerial stock ownership increases, then the decision is made to the value-oriented companies.

\section{Conclusion}

The difference in the proportion of managerial stock ownership may influence varied impact on the firm value. This study as well as provided is approval against the study by Lee and Ryu(2003) which states that managerial ownership as an influence on the value of the company depending on the proportion of the ownership. The results of this study showed the linear testing; managerial ownership has insignificant effect on the firm value, but based on the proportion of managerial ownership has the effect of non-linear (U-shaped) on the firm value. Once in this study gives an indication of support for the existence of an alignment of interest and in the entrenchment effect of managerial ownership effect on the firm value.

\section{References}

[1]. Benson, Bradley W and Davidson, Wallace N III (2009). Reexamining the Managerial Ownership Effect on Firm Value. Forthcoming: Journal of Corporate Finance 2009

[2]. Bearly, Adolf dan Means, Gardiner.C. 1932. The Modern Corporation and Private Property. Sumber : http://www.unz.org/Pub/BerleAdolf-1932?View=PDF

[3]. Din, Shahab-u and Javid, Attiya Yasmin (2011). Impact of Managerial Ownership on Financial Policies and the Firm's Performance: Evidence Pakistani Manufacturing Firms. MPRA Paper No. 37560, Posted 29. March 2012

[4]. Faccio, Mara and Lasfer, M. Ameziane (1999). Managerial Ownership, Board Structure and Firm Value: The UK Evidence. Paper Social Science Research Network (SSRN) http://papers.ssrn.com/sol3/papers.cfm?abstract id=179008

[5]. Fahlenbrach, Rüdiger and Stulz, Rene (2008). Managerial Ownership Dynamics and Firm Value. Fisher College of Business Working Paper Series, January 2008

[6]. Hamidullah and Shah, Attaullah (2011). The Impact of Ownership Structure on Capital Structure and Firm Value: Evidence from the KSE-100 Index Firms. International Conference on Management, Economics and Social Sciences (ICMESS'2011) Bangkok Dec., 2011

[7]. Herry and Hamin (2005). Tingkat Kepemilikan Manajerial dan Nilai Perusahaan: Bukti Empiris pada Perusahaan Publik di Indonesia. Simposium Riset Ekonomi II Surabaya, 23-24 November 2005

[8]. Hiraki, Takato; Inoue, Hideaki; Ito, Akitoshi; Kuroki, Fumiaki and Masuda, Hiroyuki (2001). Corporate Governance and Firm Value in Japan: Evidence from 1985 to 1998. Paper Social Science Research Network (SSRN): http://papers.ssrn.com/sol3/papers.cfm?abstract_id $=416941$

[9]. Indonesian Stock Exchange. IDX Statistics 2008-2010

[10]. Indonesian Stock Exchange. IDX Annual Report 2008-2010

[11]. SWA. IICG Report 2008-2010

[12]. Iturralde, D. Txomin; Maseda, D. Amaia and Arosa, D. Blanca. (2011). Insiders Ownership and Firm Performance. Empirical Evidence. International Research Journal of Finance and Economics Issue 67 (2011) 
[13]. Jensen and Meckling (1976). 1976. Theory of the Firm: Managerial Behavior, Agency Costs and Ownership Structure. Journal of Financial Economics, October, 1976, V. 3, No. 4, pp. 305-360

[14]. Kamal, Miko. (2011). Konsep Corporate Governance di Indonesia: Kajian atas Kode Corporate Governance. Jurnal Manajemen Teknologi Volume 10 Number 2 (2011) pp 154-161

[15]. Kim, Kenneth A; Kitsabunnarat; Pattanaporn and Nofsinger, John R. (2011). Ownership and Operating Performance in An Emerging Market: Evidence from Thai IPO Firms. Journal of Corporate Finance 10 (2004) 355 - 381

[16]. Lee, Sang-Mook and Ryu, Keunkwan (2003). Management Ownership and Firm's Value: An Empirical Analysis using Panel Data. The Institute of Social and Economic Research Osaka University, September 2003

[17]. Morck, Andrei and Vishny, Robert W. (1988). Management Ownership and Market Valuation: An Emprical Analysis. Journal of Financial Economics 20 (1988) 293-315

[18]. Mueller, Elisabeth and Spitz, Alexandra (2002). Managerial Ownership and Firm Performance in German Small and Medium-Sized Enterprises. The Centre for Economic Performance is financed by the Economic and Social Research Council, December 2001

[19]. Ministry of Finance and Bapepam-LK (2010). Efektivitas PP Nomor 81 Tahun 2007 dan PMK Nomor 238/PMK.03/2008 terhadap Peningkatan Jumlah Emiten dan Kepemilikan Saham Publik

[20]. Ruan, Wenjuan; Tian, Garry and Ma, Shiguang. (2011); Managerial Ownership, Capital Structure and Firm Value: Evidence from China's Civilian-run Firms. Australasian Accounting Business and Finance, Vol 5 Issue 3

[21]. Rustendi, Tedi and Jimmi, Farid (2008); Pengaruh Hutang dan Kepemilikan Manajerial terhadap Nilai Perusahaan pada Perusahaan Manufaktur. Jurnal Akuntansi FE Unsil, Vol. 3, No. 1, 2008

[22]. Simoneti, Marko and Gregoric, Aleksandra (2004). Managerial Ownership and Corporate Performance in Slovenian PostPrivatisation Period. The European Journal of Comparative Economics Vol. 1, n. 2, 2004, pp. 217-241

[23]. Torre, Blanca Arosa; Jainaga, Txomin Iturralde and Garcia, Amaia Maseda. (2011). Insiders Ownership and Generational Phase in SMES Family Firms. XXV Congreso Anual De Aedem - Ponencia Valencia 8, 9 Y 10 De Junio De 2011

[24]. Wahla, Khalil-Ur-Rehman; Ali Shah, Syed Zulfiqar and Hussain, Zahid (2011). Impact of Ownership Structure on Firm Performance Evidence from Non-Financial Listed Companies at Karachi Stock Exchange. International Research Journal of Finance and Economics ISSN 1450-2887 Issue 84 (2012) 